\title{
Occurrence of Antibiotic Resistant Bacteria in Raw and Pasteurized Milk Samples of Warangal City, Telangan State
}

\author{
G. Srujana* and V. Krishna Reddy \\ Department of Botany, Kakatiya University, Warangal-506009, Telangana State, India \\ *Corresponding author
}

\begin{abstract}
A B S T R A C T
Keywords

Antibiotic

Resistant Bacteria,

Raw and

Pasteurized Milk.

Article Info

Accepted:

12 June 2016

Available Online:

10 July 2016

In the present study investigations on occurrence of antibiotic resistant bacteria in raw and pasteurized milk supplied to Warangal city, Telangana state was carried out. All the raw and pasteurized milk samples collected from different mandals of Warangal were recorded to contain antibiotic resistant bacteria. However, the levels of resistance differed according to the sample. Ampicillin and erythromycin resistant bacteria were found in all samples indicating that their wide use in dairy industry. Furazolidine and kanamycin were detected in least number of samples. Chloramphenicol, gentamycin, nalidixic acid and neomycin resistant bacteria were not detected in any of the samples.
\end{abstract}

\section{Introduction}

Milk, an essential food for human beings, supports the growth of many microorganisms serving as an ideal medium. Raw milk is an ideal growth medium for several microorganisms especially Lactobacillus, Staphylococcus, and Micrococcus species. Bacterial contamination of raw milk can originate from several sources such as milch animal, air, milking equipment, feed, soil faeces and grass (Pant et al., 2013).

During the last few decades, development of antibiotic resistance in bacteria has been identified as a major worldwide clinical and public health problem (Levy, 2002).
Antibiotic resistant bacteria cannot be controlled or killed by antibiotics. The increased use of antibiotics, both in human or animal medicine is considered as prime factor in spreading the antibiotic resistance (Aarestrup, 1999; Levy and Marshall, 2004, Hawkey and Jones, 2009). Many investigators believe that these drug resistant organisms have become more common recently due to the extensive use of antibiotics in medicine and agriculture throughout the world. (Grabow et al., 1914; Hinshow et al., 1969; Mitshashi 1977; Vanrensburg et al., 1975). Not only the antibiotic use in human medicine has been linked to the elevated antibiotic resistance in 
bacteria, but also the use of antibiotics in veterinary medicine, agriculture, aquaculture, horticulture and other human activities has been identified as the other driving forces in escalating the problem (Aarestrup, 1999; Barbosa and Levy, 2000; Aminov, 2009). Antibiotic resistance in pathogens poses problem in effectively treating the human infections, but antibiotic resistance in non-pathogens is also important because of the ability of these organisms to transmit resistance to other organisms by means of transmissible resistance factors (R-factors) (Datta, 1969; Feary et al., 1972; Smith, 1969; Van Gravenitz, 1977).

In view of the importance of antibiotic resistance in bacteria, the present studies were aimed at to assess the occurrence of antibiotic resistance bacteria in raw and pasteurized milk sources of Warangal city Telangana state, India.

\section{Material and Methods}

\section{Milk sampling}

Milk samples were collected at weekly intervals in the morning hours, during the period 2009 to 2011. Samples were collected in sterile screw cap tubes labeled with the sample code and transported to the laboratory in an icebox and stored at $4^{\circ} \mathrm{C}$. The samples were processed and analysed within two hours of sampling. Different aspects of milk such as source, storage, transport, container, duration were carefully recorded.

\section{Antibiotic resistance testing}

Antibiotic susceptibility of bacterial isolates was determined using antimicrobial impregnated paper discs applied on to Muller-Hinton agar (Bauer et al., 1966;
NCCLS 2000). Different antibiotic (ampicillin, chloramphenicol, erythromycin, furazolidone, gentamycin, kanamycin, nalidixic acid, neomycin, oxytetracylin, streptomycin, tetracycline) discs containing $(10,30 \mathrm{mg} /$ disc $)$ were used. Himedia was used to determine the antibiotic sensitivity. Twenty four hours old cultures of bacterial isolates were diluted with $9.0 \mathrm{ml}$ of sterile agar solution $(1.5 \%)$ such that a population of $10^{5}-10^{6}$ bacteria was obtained. This suspension was spread over the surface of petri plate containing Muller Hinton agar and allowed to stand for 5 minutes. Antibiotic discs were aseptically applied and incubated for 24 hours at $37^{\circ} \mathrm{C}$. Zone of inhibition around the discs was measured using antibiotic zone scale (Himedia) and the diameters of the zones were recorded to the nearest millimeter.

\section{Results and Discussion}

The incidence of resistant bacteria against different antibiotics in raw milk samples collected from different mandals was evaluated and the results are presented in table -1 . A critical study of the table reveals that all the samples from different mandals were found to contain antibiotic resistant bacteria. Maximum incidences of antibiotic resistant bacteria were, recorded in samples of Hanamkonda mandal followed by Dharmasagar mandal, Ghanpur mandal and Jangaon mandal. Least number was recorded in samples of Narsampet mandal. Analysis of incidence of bacteria against individual antibiotics reveals that all samples contained ampicillin resistant bacteria. Next to ampicillin erythromycin resistant bacteria were recorded in all the samples. Resistant bacteria against oxytetracyclin, streptomycin and tetracycline were found in few samples from different places. 
Table.1 Occurrence of antibiotic resistant bacteria in different raw milk samples

\begin{tabular}{|c|c|c|c|c|c|c|c|c|c|c|c|c|c|c|}
\hline & & & & \multicolumn{11}{|c|}{ Antibiotics } \\
\hline S.No & Source & $\begin{array}{c}\text { Total } \\
\text { number of } \\
\text { strains }\end{array}$ & $\begin{array}{l}\text { No. of } \\
\text { resistant } \\
\text { strains }\end{array}$ & $\begin{array}{l}. \Xi \\
\stackrel{\Xi}{\Xi} \\
. \bar{Z}\end{array}$ & 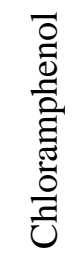 & 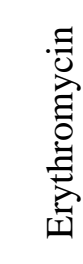 & 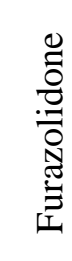 & 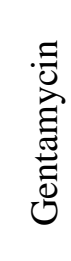 & 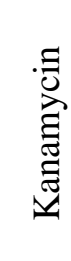 & 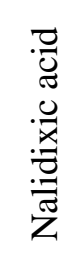 & 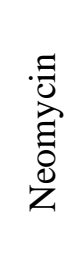 & 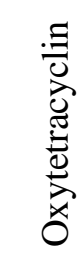 & 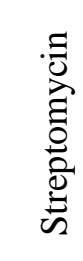 & 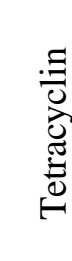 \\
\hline 1 & AM & 10 & 8 & 5 & - & 2 & - & - & - & - & - & - & 1 & - \\
\hline 2 & $\mathrm{DM}$ & 10 & 9 & 2 & - & 4 & - & - & - & - & - & 2 & - & 1 \\
\hline 3 & GM & 10 & 9 & 3 & - & 1 & - & - & - & - & - & 3 & 1 & 1 \\
\hline 4 & HM & 10 & 10 & 4 & - & 2 & - & - & - & - & - & 1 & 2 & 1 \\
\hline 5 & HP & 10 & 7 & 3 & - & 2 & - & - & 1 & - & - & - & 1 & - \\
\hline 6 & $\mathrm{JM}$ & 10 & 9 & 2 & - & 4 & - & - & - & - & - & 1 & 2 & - \\
\hline 7 & MM & 10 & 8 & 3 & - & 3 & - & - & - & - & - & 1 & 1 & - \\
\hline 8 & NM & 10 & 6 & 3 & - & 2 & 1 & - & - & - & - & 0 & - & - \\
\hline 9 & PM & 10 & 7 & 2 & - & 2 & - & - & - & - & - & 2 & - & 1 \\
\hline 10 & WM & 10 & 7 & 1 & - & 2 & - & - & 1 & - & - & 1 & 1 & 1 \\
\hline & Total & 100 & 80 & 28 & - & 24 & 1 & - & 2 & - & - & 11 & 9 & 5 \\
\hline
\end{tabular}

AM=Athamakur mandal, DM=Dharmasagar mandal, GM=Ghanpur mandal, HM=Hanamkonda, HPM=Hasanparthy, JM=Jangaon mandal, $\mathrm{MM}=$ Mulug mandal, $\mathrm{NM}=$ Narsampet mandal, $\mathrm{PM}=$ Parkal mandal, WM=Wardhannapet mandal. 
Table.2 Occurrence of antibiotic resistant bacteria in milk supplied by different dairy farms

\begin{tabular}{|c|c|c|c|c|c|c|c|c|c|c|c|c|c|c|}
\hline \multirow[b]{2}{*}{ S.No } & \multirow[b]{2}{*}{ Source } & \multirow[b]{2}{*}{$\begin{array}{c}\text { Total } \\
\text { number of } \\
\text { strains }\end{array}$} & \multirow[b]{2}{*}{$\begin{array}{c}\text { No. of } \\
\text { resistant } \\
\text { strains }\end{array}$} & \multicolumn{11}{|c|}{ Antibiotics } \\
\hline & & & & 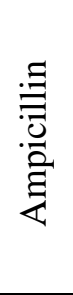 & 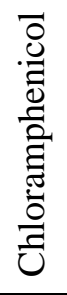 & 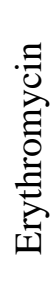 & 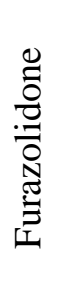 & 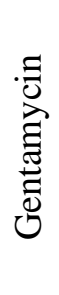 & 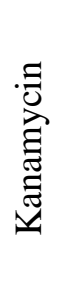 & 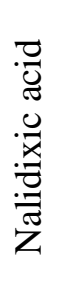 & 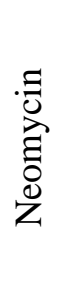 & 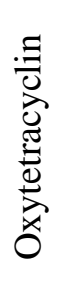 & 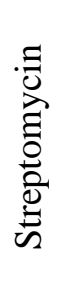 & 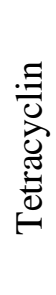 \\
\hline 1 & $\mathrm{AG}$ & 13 & 6 & 3 & & 2 & - & - & - & - & - & - & 1 & - \\
\hline 2 & $\mathrm{DP}$ & 13 & 8 & 5 & - & 1 & - & - & - & - & - & 1 & - & 1 \\
\hline 3 & HT & 13 & 4 & 2 & - & 1 & - & - & - & - & - & - & 1 & - \\
\hline 4 & JR & 13 & 8 & 3 & - & 1 & - & - & - & - & - & 1 & 2 & 1 \\
\hline 5 & MK & 13 & 7 & 3 & - & 2 & - & - & 1 & - & - & - & 1 & - \\
\hline 6 & ML & 13 & 10 & 3 & - & 4 & - & - & - & - & - & 1 & 2 & - \\
\hline 7 & MD & 13 & 5 & 2 & - & 1 & - & - & - & - & - & 1 & 1 & - \\
\hline 8 & NJ & 13 & 6 & 3 & - & 2 & 1 & - & - & - & - & - & - & - \\
\hline 9 & PR & 13 & 9 & 3 & - & 2 & - & - & - & - & - & 3 & - & 1 \\
\hline 10 & TM & 13 & 4 & 2 & - & 1 & - & - & - & - & - & 1 & - & - \\
\hline 11 & VJ & 13 & 3 & 1 & - & & - & - & - & - & - & 1 & - & 1 \\
\hline 12 & $\mathrm{VS}$ & 13 & 5 & 2 & - & 1 & - & - & - & - & - & 1 & 1 & - \\
\hline 13 & WD & 13 & 9 & 3 & - & 2 & - & - & - & - & - & 2 & 1 & 1 \\
\hline & Total & 169 & 84 & 35 & 0 & 20 & 1 & 0 & 1 & 0 & 0 & 12 & 10 & 5 \\
\hline
\end{tabular}

AG=Agrigold, DSP=Dairy Pure, HT=Heritage, JR=Jercey, MK=Mukunda, ML=Mulkanoor, MD=Mother Dairy, NJ=Nagarjuna,

$\mathrm{PR}=$ Priya, $\quad \mathrm{TM}=$ Thirumala,

$\mathrm{VJ}=\mathrm{Vijaya}$,

VS=Vaishnavi,

WD=Wardhanpe 
Ampicillin, erythromycin and furazolidone resistant bacteria were recorded Narsampet mandal samples. Kanamycin resistant bacteria were found in samples of Hasanparthy mandal and Wardhannapet mandal Bacteria resistant against four antibiotics, chloramphenicol, gentamycin, nalidixic acid and neomycin were recorded in none of the samples.

Data presented in table-2 reveals the occurence of antibiotic resistant bacteria in pasteurized milk supplied by commercial dairy farms. It is evident from the critical study of the table that the incidence of antibiotic resistant bacteria varied according to the milk brand. The highest number of resistant bacteria was found in samples of Mulkanoor narrowly followed by Priya and Jercey and also Dairy Pure. The least number of resistant bacteria were recorded in Vijaya. The number and sensitivity of resistant bacteria also varied with the sample. Ampicillin resistant bacteria were recorded in the milk of all brands. Similarly erythromycin resistant bacteria were recorded in all milk brands except in Vijaya. Furozolidone resistant bacteria were recorded in Nagarjuna, whereas kanamycin resistant bacteria were found only in Mukunda sample. Oxytetracyclin resistant bacteria were recorded in the milk of almost all brands except in samples of Agrigold, Heritage, Mukunda and Nagarjuna. Streptomycin resistant bacteria were recorded in milk samples of Agrigold, Heritage, Jercey, Mukunda, Mulkanoor, Mother dairy, Vaishnavi and Wardhanpet. A few brands milk was found to contain tetracycline resistant bacteria. On the whole, order of occurences of antibiotic wise resistant bacteria was ampicillin > erythromycin > oxytetracyclin $>$ tetracycline $>$ furazolidone $>$ kanamycin. No samples were found to contain gentamycin, nalidixic acid and neomycin resistant bacteria.
It is evident from the present investigations that antibiotic resistant bacteria are common both in raw and commercial brand pasteurized milk samples. These bacteria play a significant role in the spoilage of milk transmitting the diseases. Yet, another possibility is that the resistance may be transmitted horizontally to other milk inhabiting bacteria.

\section{Acknowledgement}

The authors are thankful to the Head, Department of Microbiology and Botany for providing laboratory facilities.

\section{References}

Aarestrup. F.M. 1999. Association between the consumption of antimicrobial agents in animal husbandry and the occurrence of resistant bacteria among food animals. Int. J. Antimicrob. Agents, 12(4): 279-85.

Aminov. R.L. 2009. The role of antibiotics and antibiotic resistance in nature. Environ. Microbiol., 11(12): 2970-88.

Barbosa, T.M., Levy, S.B. 2000. The impact of antibiotic use on resistance development and persistence. Drug Resist Update, 3(5): 303-11.

Datta, N. 1969. Drug resistance and Rfactors in the bowel bacteria of London plaints before and after admission to Hospital. British Med. J., 407- 411.

Feary, J.W., Sturtevant, A.B and Lank ford, J. 1972. Antibiotic resistant coliforms in fresh and salt water. Arch. Environ. Health, 25: 215-220.

Grabow, W.O.K., Prozesky O.W. and smith, L.S. I974. Drug resistant coliforms all for review of water quality standards. Water Res., 8: 1-9.

Hinshaw, V., Punch, J., Allision, M.J., Datton, H.P. I969. Frequency of RFactor mediated multiple durg 
resistance in Klebsiella and Acrobacter. Appl. Environ. Microbiol., 17: 214-218.

Levy, S.B., Marshall, B. 2004. Antibacterial resistance worldwide: Causes, challenges and responses. Nat. Med., 10(Supple 12): S 122-9.

Mitsuhashi, S. 1977. Epidemiology of bacterial drug resistance, P.3-24. In S.Mitguhasli (ed), R-factor drug resistance plasmid. University Park Press, Baltimore.

Pant, R., Nirwal, S., Rai, N. 2013. Int. J. Pharm. Tech. Res., CODEN (USA): ijprifissn. 5: 804-810.

Sizemore, R.K., Colwel, R.R. 1977. Plasmids Carried by antibiotic resistant marine bacteria Antimicrob. Agents chemother., 12: 313-382.

Smith, H.W. 1969. Transfer of antibiotic resistance from animal and human strains of E.coli to resident E.coli in the alimentary tract of man. Lancet, 11741176.

Van Graevenitz, A. 1977. The role of opportunistic bacteria in human disease. Annual Rev. Microbiol., 31: 447-471.

Vanrensburg, 1.J., Dekock, M.J., Van Rensburg. A.J. 1975. Antibiotic Resistance and R-factors in Klebsiella pneumoniae. South African Med. J., 1876-1878.

\section{How to cite this article:}

Srujana, G., and V. Krishna Reddy. 2016. Occurrence of Antibiotic Resistant Bacteria in Raw and Pasteurized Milk Samples of Warangal City, Telangan State. Int.J.Curr.Microbiol.App.Sci. 5(7): 337-346. doi: http://dx.doi.org/10.20546/ijcmas.2016.507.036 